\title{
Aspek Patologi dan Diagnosis Polip Kolorektal
}

\author{
Shintia Christina \\ Staf Pengajar Bagian Patologi Anatomi \\ Fakultas Kedokteran Universitas Kristen Krida Wacana, Jakarta \\ Alamat Korespondensi : shintiatc@gmail.com
}

\begin{abstract}
Abstrak
Polip kolorektal merupakan benjolan yang sering ditemukan di saluran cerna, dibandingkan polip lain di saluran pencernaan. Polip kolorektal ada yang bersifat neoplastik, ada juga yang bukan. Polip yang neoplastik dapat berprogresi menjadi maligna. Klasifikasi polip kolorektal menurut WHO adalah adenoma, serrated dan hamartoma. Semua tipe tersebut mempunyai prognosis dan tata laksana yang berbeda. Endoskopi sering dilakukan pada pasien dengan polip kolorektal, tetapi apa yang ditemukan dari endoskopi tidak bisa membedakan tipe dari polip tersebut, sehingga diperlukan pemeriksaan patologi anatomi untuk kepastian tipe polip.
\end{abstract}

Kata kunci : polip kolorektal, patologi, anatomi.

\section{Pathological Aspect and Diagnosis of Colorectal Polyps}

\begin{abstract}
Colorectal polyps are lesion often found in the gastrointestinal tract, compared to other polyps in the gastrointestinal tract, colorectal is the most common site of polyps. Colorectal polyps are neoplastic but some are not. The neoplastic polyps have the ability to become malignant. According to WHO the classification of colorectal polyps is adenoma, serrated and hamartoma. All of these types have different prognoses and management. Endoscopy is often performed in patients with colorectal polyps, but what is found from endoscopy can not distinguish the type of the polyp, anatomical pathology is required for certainty of polyp type.
\end{abstract}

Keywords : colorectal polyp, pathology, anatomy

\section{Pendahuluan}

Defisini polip adalah semua massa yang menonjol ke dalam lumen, baik di saluran gastrointestinal, genitourinarius, dan respiratorius. Polip timbul dari lapisan mukosa, juga bisa berasal dari submukosa dan ada juga yang berasal dari proliferasi sel mesenkimal dan hematolimfoid. ${ }^{1,2}$ Polip kolorektal dibagi menjadi polip neoplastik (adenoma), hiperplastik, hamartoma, dan inflamatori. ${ }^{1}$ WHO membaginya sedikit berbeda yaitu menjadi adenoma, serrated dan hamartoma. Adenoma sendiri dibagi menjadi tiga yaitu tubular, tubulovilosum dan vilosum. Jenis tubular merupakan jenis yang paling besar berpotensi menjadi suatu keganasan yaitu sebesar 38,4\%. Polip serrated terdiri dari polip hiperplastik, sessile serrated adenoma (SSA), traditional serrated adenoma (TSA) dan mixed polip (MP). Polip Hamartoma terdiri atas polip pada penderita Cowden, polip Peutz-Jeghers dan polip juvenile. $^{3}$

Prevalensi polip kolon adenomatosa bervariasi di berbagai negara, dengan kecenderungan lebih tinggi pada negara-negara 
maju. $^{4}$ Di Indonesia, pusat endoskopi Cipto Mangunkusumo, Jakarta tahun 2007, melaporkan dari 662 pasien yang menjalani pemeriksaan kolonoskopi dengan indikasi apa pun ; 23,2\% di antaranya didapati polip dan kanker kolorektal. ${ }^{5}$ Pada penelitian dengan sampel sebanyak 1.050 polip kolon, $82 \%$ adalah adenoma, $12 \%$ hiperplastik, $3 \%$ inflamatorik, dan $1,5 \%$ adalah polip mesenkimal yaitu lipoma dan leiomioma. ${ }^{2}$ Pada penelitian di RS Tarakan, Jakarta Pusat diperoleh data jumlah polip inflamatorik sebesar $47,1 \%$, diikuti polip adenoma $39,1 \%{ }^{4}$

Polip yang berpotensi menjadi karsinoma kolorektal adalah yang neoplastik, sehingga penting untuk mengenalinya. ${ }^{1}$ Polip kolorektal neoplastik disebut juga adenoma, yang masih bersifat jinak dan berasal dari sel epitel mukosa kolon. ${ }^{6}$ Pemeriksaan histopatologis untuk mengetahui secara pasti jenis polip, hal ini penting sekali karena jenis-jenis polip yang tidak dapat dibedakan secara klinis, masing-masing jenis mempunyai potensi menjadi ganas yang berbeda. $^{6}$ Adenoma kolorektal merupakan prekursor terjadinya kanker kolorektal, terutama melalui jalur microsatellite instable. ${ }^{6}$

Pemeriksaan penapisan dengan kolonoskopi pada orang di atas usia 50 tahun di Amerika Serikat didapatkan $20-40 \%$ penderita polip adenoma. Pada usia $<50$ tahun didapatkan $12 \%$ wanita dan $24 \%$ pria menderita adenoma, sedangkan pada usia $>80$ tahun didapatkan $27 \%$ wanita dan $40 \%$ pria menderita adenoma. ${ }^{1}$

\section{Polip Menjadi Kanker}

Adenoma merupakan kanker lesi prekursor. ${ }^{1,6,7}$ Semua kanker kolorektal berasal dari polip adenoma, tetapi kecepatan adenoma menjadi kanker tidak diketahui secara pasti, diduga sekitar 5-10 tahun sejak terdeteksi polip. ${ }^{1}$ Pada penelitian dimana polip dihilangkan, pasien dengan adenoma tubular $\geq 10 \mathrm{~mm}$, adenoma vilosum dengan dIsplasia keras/bagian invasif lebih tinggi kemungkinan menjadi karsinoma. ${ }^{8}$

WHO tahun 2010 membuat klasifikasi polip dengan menambahkan polip serrated yang dibagi menjadi polip hiperplastik, SSA, TSA, dan MP. Pengertian dahulu mengenai polip hiperplastik adalah polip yang indolent, hiperproliferatif, dan non-neoplastik. Saat ini diketahui bahwa subtipe polip serrated dapat berubah menjadi karsinoma melalui jalur serrated. ${ }^{9}$ Pengertian mengenai molekular yang semakin berkembang membuat pemahaman bahwa karsinoma kolorektal timbul melalui beberapa jalur, dimana polip serrated merupakan salah satu prekursor. Pada jalur serrated terdapat subtipe SSA dan TSA yang telah terbukti merupakan kontributor penting terjadinya karsinoma kolorektal. ${ }^{9}$

Risiko polip menjadi karsinoma tergantung dari beberapa faktor, di antaranya adalah ukuran. Penelitian menyatakan ukuran $<5 \mathrm{~mm}$ risiko disertai displasia keras $<1 \%$ dan risiko menjadi karsinoma dapat diabaikan, sedangkan ukuran $>$ $5 \mathrm{~mm}$ mempunyai risiko $3 \%$ menjadi karsinoma. ${ }^{1}$ Polip sessile berukuran 6-10 mm menunjukkan invasi submukosal sebesar 24\% dibandingkan dengan lesi yang pedunculated yaitu sebesar $1,3 \%$, dengan angka yang terus meningkat dengan meningkatnya ukuran lesi. ${ }^{10}$

\section{Pemeriksaan Deteksi Dini Polip}

Pemeriksaan yang bisa dilakukan adalah tes darah samar pada feses, fecal immunochemical testing, kolonoskopi, kolonoskopi spektroskopi, narrow band imaging, computed tomographic colonography, magnetic resonance colonography, capsule endoscopy, fecal DNA and antigen testing. ${ }^{1}$

Kolonoskopi adalah pemeriksaan baku emas untuk mendeteksi adanya lesi intralumen kolon, walaupun sensitivitasnya tidak mencapai $100 \%$. Satu systematic review menyatakan angka kesalahan/miss rate untuk adenoma berukuran $10 \mathrm{~mm}$ adalah $2,1 \%$, ukuran $5-10 \mathrm{~mm}$ adalah $13 \%$, ukuran 1-5 mm adalah $26 \%$. WHO merekomendasikan untuk dilakukan kolonoskopi setiap lima tahun sekali setelah berusia 50 tahun, sedangkan American Cancer Society menyarankan kolonoskopi lengkap setiap sepuluh tahun dimulai dari usia 50 tahun. ${ }^{1}$

Narrow band imaging mempunyai akurasi yang tinggi dengan area under curve lebih dari $90 \%$ dengan sensitivitas $>90 \%{ }^{11}$ Sensitivitas dan spesifisitas yang baik untuk membedakan lesi neoplastik dan non-neoplastik, namun modalitas ini belum digunakan secara rutin. ${ }^{1}$ kolonoskopi spektroskopi juga cukup 
menjanjikan, namun saat ini masih dalam tahap eksperimental.

\section{Aspek Patologi pada Polip Kolorektal}

Klasifikasi polip seperti telah disebutkan di atas, yang terpenting adalah membedakan polip neoplastik dan bukan neoplastik. Adenoma dan polip serrated merupakan polip yang neoplastik Adenoma didefinisikan menurut WHO sebagai adanya epitel yang mengalami displasia. Secara histopatologi ditandai oleh inti sel yang membesar, hiperkromatik, kehilangan polaritas, dan bertumpuk. Displasia dibagi menjadi derajat
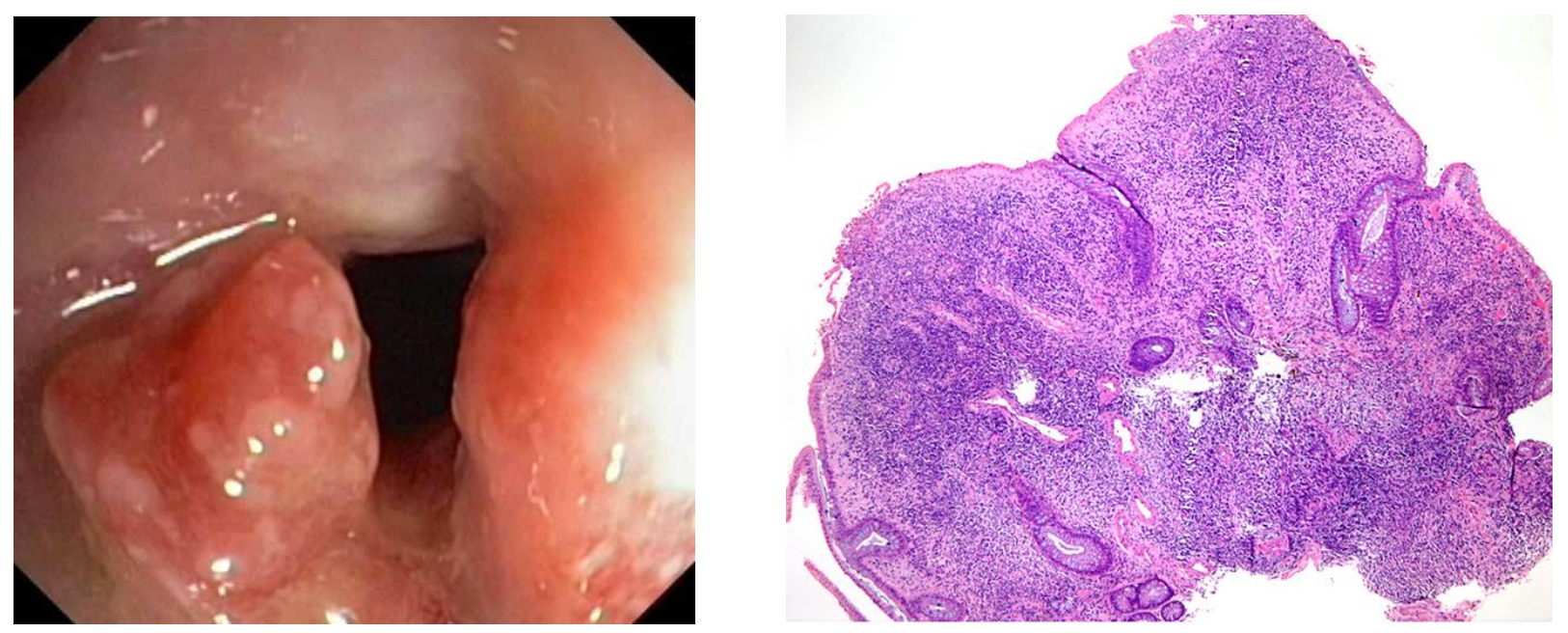

Gambar 1. A. Tampilan polip inflamatorik. B. Polip inflamatorik dengan epitel pelapis erosif dan sebukan keras sel radang $(\mathrm{HE}, 40 x){ }^{12}$

Lesi serrated dibagi menjadi tiga yaitu polip hiperplastik, sessile serrated adenoma, dan traditional serrated adenoma. Polip hiperplastik biasanya berukuran $<0,5 \mathrm{~cm}$ dan terletak di kolon desenden. Secara histopatologi tampak matur dengan permukaan epitel yang irregular "saw tooth"/"serrated". Arsitektur tubular rendah dan derajat tinggi tergantung pada kompleksitas arsitektur kelenjar, stratifikasi inti, dan morfologi inti. ${ }^{3}$

Polip non-neoplastik adalah polip inflamatorik yang merupakan penonjolan mukosa intraluminal, yang terdiri dari komponen epitelial dan mesenkimal, serta sel-sel radang. ${ }^{2}$ Polip inflamatorik menunjukkan mukosa yang meradang dengan epitel permukaan yang erosis dikelilingi oleh jaringan granulasi dan distorsi epitel. ${ }^{12}$ Makroskopik bisa sessile/pedunkulasi dengan ukuran biasa di bawah $3 \mathrm{~cm}^{12}$ (Gambar 1A dan 1 B). 

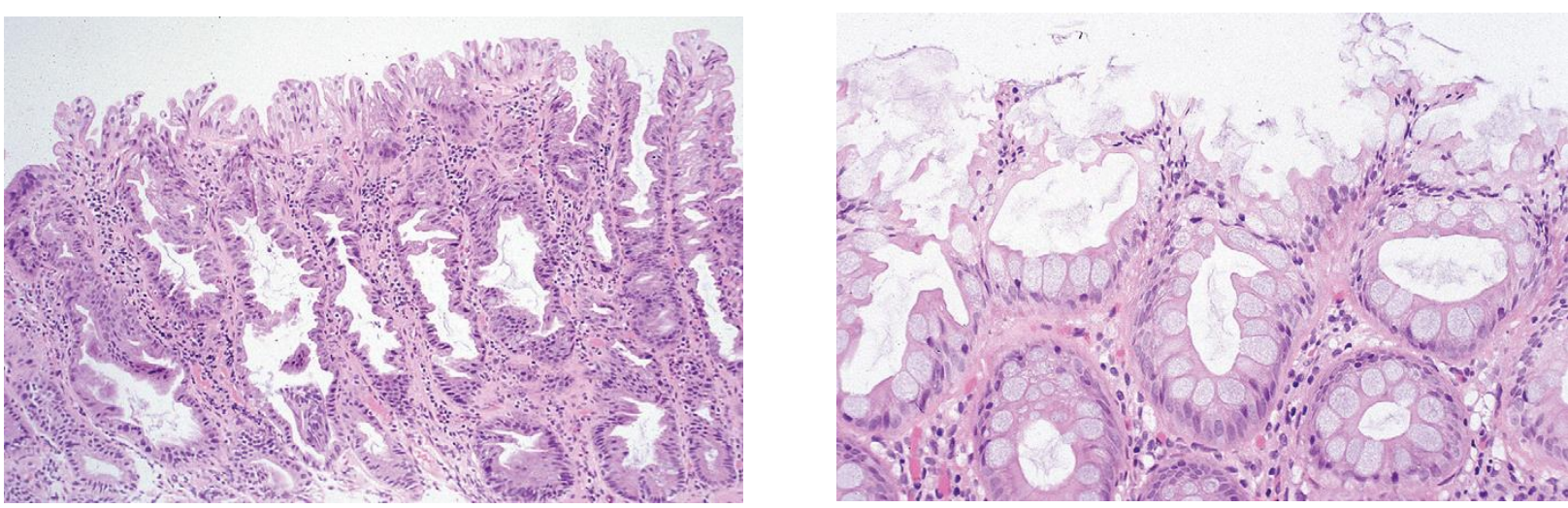

Gambar 2. A. Polip hiperplastik tipe "mucin poor""menunjukkan inti epitel yang hiperkromatik dengan deplesi musin (HE, 40x). B. Polip hiperplastik tipe "goblet cell-rich" dengan epitel mengandung banyak sel goblet dan sedikit gambaran "serrated".

Sessile serrated adenoma (SSA) biasa berukuran $>0,5 \mathrm{~cm}$ dan terletak di kolon asenden. ${ }^{2}$ Morfologi polip ini adalah adanya dilatasi kripta, iregularitas kripta, gambaran serrated lebih mencolok di bagian bawah, mitosis, dan inti vesikuler di bagian atas kripta, hipermusinosum epitel, dan pertumbuhan epitel yang endofitik/inverted. ${ }^{2}$. Bagian basal kripta bercabang dan kadang membentuk seperti hutuf T terbalik. ${ }^{2}$

Kolonoskopi dari polip serrated merupakan hal yang menantang karena sering tidak jelas, dengan batas tidak jelas dan tertutup mukus yang melekat. ${ }^{9}$ Sessile serrated adenoma mempunyai gambaran molekular yaitu pada instability microsatellite dan fenotip mutilator, mengindikasikan bahwa SSA merupakan prekursor keganasan. ${ }^{9}$ Kurang lebih $15 \%$ pasien dengan SSA akan menjadi polip adenoma dengan displasia keras atau karsinoma kolorektal. Bila ukuran lebih dari $1 \mathrm{~cm}$ maka risiko menjadi karsinoma kolorektal meningkat. Tatalaksana SSA adalah dengan polipektomi, direkomendasikan untuk mengambil semua lesi hingga lebih dari $5 \mathrm{~mm}$ dari rektosigmoid. Lesi dengan ukuran $>1 \mathrm{~cm}$ atau dengan dysplasia keras sebaiknya diperlakukan sebagai adenoma risiko tinggi ${ }^{13}$ (Gambar 3).

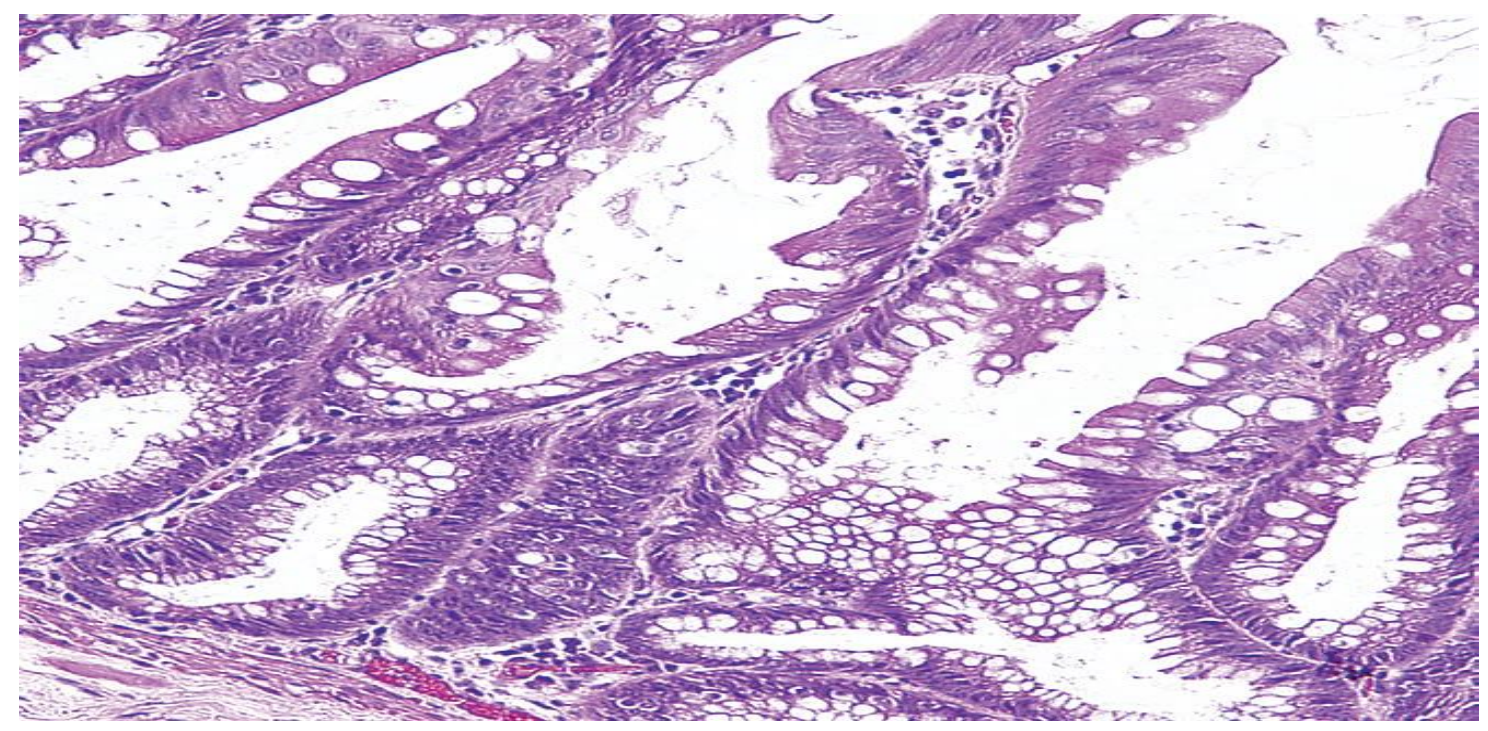

Gambar 3. Sessile serrated adenoma. Menunjukkan dasar kripta yang melebar dibandingkan permukaan, bedakan dengan polip hiperplastik dimana dasar sama dengan permukaan. ${ }^{14}$ 
Polip adenoma merupakan lesi yang asimtomatik, ada beberapa dengan perdarahan rektum. Terdapat empat faktor untuk terjadinya adenoma kolorektal: lingkungan, genetik, diet dan faktor host. ${ }^{2,14}$ Adenoma yang berukuran besar $(>1 \mathrm{~cm})$ lebih sering pada kolon desenden.
Adenoma dibagi menjadi tubular, vilosum dan tubulovilosum dengan inti bertumpuk dan besar serta anak inti mencolok, deplesi musin, dan mitosis yang banyak ${ }^{14}$

(gambar 4A dan 4 B).
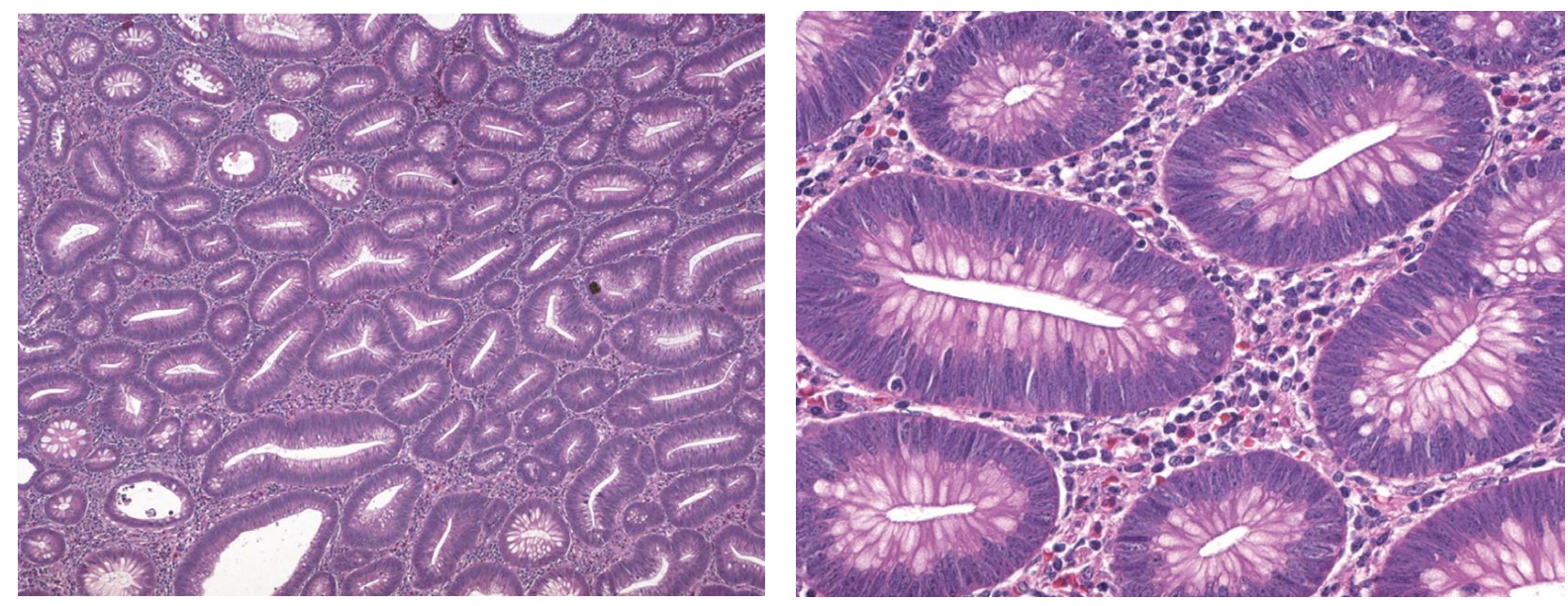

Gambar 4. A. Adenoma tubular dengan struktur tubular padat. B. Inti pada adenoma dengan displasia ringan menunjukkan inti membesar dan elongasi, inti bertumpuk dengan anak inti nyata, mitosis sering ditemukan dan musin deplesi. ${ }^{14}$

\section{Ringkasan}

Polip kolorektal mempunyai gambaran secara makroskopik dari pemeriksaan endoskopi yang tidak dapat dibedakan jenisnya, sehingga dibutuhkan pemeriksaan patologi anatomi untuk membedakan jenis-jenis polip. Pentingnya mengetahui jenis-jenis polip adalah untuk penentuan tata laksana dan prognosis pasien.

\section{Daftar Pustaka}

1. Shussman N, Wexner S.D. Colorectal polyps and polyposis syndromes. Gastroenterology Report. 2014; p.1-15.

2. Hornick JL, Odze RD. Polyps of the large intestine. In : Odze RD, Goldblum JR, editors. Surgical pathology of GI tract, liver, biliary tract and pancreas. $2^{\text {nd }}$ ed. 2009. Philadelphia. Saunders.

3. Hamilton SR, Bosman FT, Boffetta P,et al. Carcinoma of the colon rectum. In: Bosman FT, Carneiro F, Hruban RH,
Theise ND, editors. WHO classification of tumours of the digestive system. $4^{\text {th }}$ ed. Internation agency on research of cancer. France,Lyon. 2010; p.133, 139-40.

4. Itzkowitz SH, Jeremy R. Colonic poyps and polyposis syndrome. Dalam: Gastroenterologi and liver disease. 8th ed. WB Saunders; 2006. p.2713-50.

5. Pribadi J, Abdullah M, Simadibrata $M$ et al. Colorectal neoplasm in symptomatic Indonesian population: result of the colonoscopy examination. Gastroenterol hepatol 2008; S(5):23-5.

6. Fu Z, Shrubsole MJ, Smalley WE,et al Lifestyle factors and their combined impact on the risk of colorectal polyps. American'journal of epidemiology. 2012; p.766-76.

7. Korbar B, Olofson AM, Miraflor AP,et al. Deep learning for classification of colorectal polyps on whole-slide images. Journal of Pathology Informatics. 2017; p.1-8. 
8. Lieberman D, Moravec M, Holub J, et al Polyp size and advanced histology in patients undergoing colonoscopy screening: implications for CT colonography. Gastroenterology. 2008; 1100-5.

9. Sweetser S, Smryk TC, Sinicrope FA. Serrated colon polyps as precursors to colorectal cancer. Clin Gastroenterol Hepatol. 2013;p. 760-7.

10. Nedrebo BS, Reite A, Thorsen K, Korner H. Endoscopy, morphology, morphometry and molecular markers: predicting cancer risk in colorectal adenoma. Expert Rev Mol Diagn. 2009; p. 125-37.

11. McGill SK, Evangelou E, Loannidis JP, et al. Narrow band imaging to differentiate neoplastic and non-neoplastic colorectal polyps in real time: a meta-analysis of diagnostic operating characteristics. Gut. 2013; 1704-13.

12. Dunn ALJ, Gonzalez RS. Inflammatory polyp of colon. Revised 7 dec 2017. www.pathologyoutlines.com/topic/colontu morinflammatory.html.

13. Kuo E, Gonzalez RS. Sessile serrated adenoma. Revised 11 january 2018. www.pathologyoutlines.com/topic/colontu morsessileserrated.html.

14. Lacobuzio-Donahue CA. Epithelial neoplasm of the colorectum. In: LacobuzioDonahue CA, Montgomery F, editors. Gastrointestinal and liver pathology. Ed:. $2^{\text {nd }}$ edition. Philadelphia, Saunders.2012. p. $410-25$. 